\title{
Epidemiology of oxacillin-resistant Staphylococcus aureus from cell phones of health-care workers in Ekiti State
}

\author{
Oluwole Moses David *, Olusola Adeoye Oluwole, Ayomide Owolabi \\ Ekiti State University, Faculty of Science, Department of Microbiology, P.M.B. 5363, Ado-Ekiti, Ekiti State \\ *Corresponding authorE-mail:davidoluwole5@gmail.com
}

\begin{abstract}
The use of mobile phones in the clinical environment by health-care workers has become widespread. A swab of mobile phones of health-care personnel of several hospitals in Ekiti State were examined to evaluate the prevalence of Oxacillin resistant Staphylococcus aureus (ORSA), the resistance of ORSA to other commonly used antibiotics as well as the multiple resistant patterns of the recovered isolates. A total of 106 samples were screened yielding $100 \mathrm{~S}$. aureus isolates. The antibiotics sensitivity profile to nine commonly used antibiotics revealed high levels of resistance amongst the isolates ranging from $47 \%$ resistance to Chloramphenicol to $100 \%$ resistance exhibited to cloxacillin with $55 \%$ of the isolates showed resistance to oxacillin while all isolates exhibited multiple resistance. Also, all 55 ORSA exhibited $100 \%$ resistance to erythromycin and cloxacillin but interestingly were very sensitive (99.9\%) to gentamicin. The high recovery rate of bacteria from mobile phones revealed that cell phones may have notable roles in the transmission of multidrug resistant nosocomial pathogens, increasing the risk of cross-contamination posed to immunosuppressed patients by the heath care workers attending to them.
\end{abstract}

Keywords: Health Care Workers; Mobile Phones; Oxacillin; S. Aureus.

\section{Introduction}

Hospital acquired infections are a problem in both developed and developing countries. It significantly increases the patients' length of stay in the hospital hence higher hospital costs. The reservoir of any organism, which may be animate or inanimate objects, in the epidemiology of any bacterial disease is very important [1-2]. Sources of HAI's can include medical staffs, the patients' own flora and inanimate hospital objects [3-4] Mobile phones are being used in all aspects of health-care delivery. They are the much preferred and most used routes of communication. However, healthcare workers' (HCW) mobile phones provide a reservoir of bacteria known to be responsible for hospital acquired infections [5]. Sadat-Ali et al. [6] reported co-contamination of oxacillinresistant (ORSA) on HCWs' hands and their mobile phones. Also, [7] reported that previously Staphylococcus aureus decolonized hands of HCWs can become contaminated by bacteria from the device. Also, [8-15] investigated the role of mobile phones and also reported role of mobile phones in transmission of infection and found out that threatening infections spread by Doctor's mobile phones and that there was an increased rate of hospital infection with use of mobile phones. Despite being used on a continuous basis, these mobile phones are seldom cleaned. They can also act as fomites for transmission of pathogenic organisms like $S$. aureus amongst other nosocomial pathogens [16]. S. aureus is considered an opportunistic pathogen responsible for great morbidity and mortality; man is its main reservoir [17]. It can be found colonizing several sites of the human body and in healthcare settings may contaminate furniture, clothes and equipment including mobile-phones of health-care workers around infected patients, which function as sources or reservoirs [18].
Oxacillin resistant $S$. aureus (ORSA) emerged during the early 60 s [19], and has since caused concerns due to nosocomial infections in human health-care [20-22]. Some strains of Methicillin resistant S. aureus have been designated epidemic strains; these are associated with a higher prevalence and have been shown to spread within hospitals, between hospitals, and between countries [2324].The prevalence of ORSA in post-operative infections accounts for up to $40 \%$ of nosocomial $S$. aureus infections in large hospitals in USA, [25], 50\% in Portugal [26], as high as 75\% in Hong Kong [27] and about $21-30 \%$ in Nigeria as reported by [28]. The epidemiology of ORSA on the cell phones of health-care workers in Ekiti State is investigated in this study.

\section{Materials and methods}

\section{Sample Collection}

A total of one hundred and six non-repeat mobile phone surface swabs were collected from healthcare facilities in Ekiti State, Nigeria. Samples were cultured on Mannitol salt agar (Oxoid) and incubated at $35^{\circ} \mathrm{C}$ for $24 \mathrm{~h}$. The discrete colonies were subcultured and incubated at the conditions earlier stated.

\section{Isolation and Identification of the Organisms}

Gram reaction and biochemical tests were conducted on the large and yellow colonies on Mannitol salt agar. Other tests carried on the isolates were slide coagulase (using rabbit plasma), catalase tests and growth in thioglycollate broth. Fermentation of maltose, mannose, lactose, sucrose and trehalose were also tested. The results of the identification procedures were interpreted according to Fawole and Oso [29] and Holt et al. [30]. 


\section{Antibiotic Sensitivity Testing}

Each of the isolates of $S$. aureus was grown at $37{ }^{\circ} \mathrm{C}$ in MuellerHinton broth (Oxoid) for $18 \mathrm{~h}$ and adjusted to an optical density of 0.5 McFarland Standard. The disc diffusion method was used for susceptibility testing as described by Clinical and Laboratory Standard Institute [31]. The isolates were tested against eight commercial antibiotic disks (Abtek Biological Limited) their concentrations in microgram in the discs were as follows: Oxacillin (5), augmentin (30), chloramphenicol (30, cotrimoxazole (25), gentamicin $(10 \mu \mathrm{g})$, erythromycin (15), amoxycillin (100) and tetracycline (30), cloxacillin (5).

\section{Results}

One hundred and six mobile phones of health-care workers (58 from nurses, 18 from doctors and 30 from laboratory scientists) from tertiary $\left(3^{\circ}\right)$, secondary $\left(2^{\circ}\right)$ and primary $\left(1^{\circ}\right)$ health-care institutions were sampled yielding $100 \mathrm{~S}$. aureus isolates. 26 isolates were recovered from the $3^{\circ}$ institutions with $86 \%$ and $93 \%$ recovery from $A$ and $B$ respectively while 31 and 43 isolates were recovered from $2^{\circ}$ and $1^{\circ}$ respectively. $100 \%$ recovery was observed in all of the $2^{\circ}$ institution workers' phones sampled while all of the $1^{\circ}$ institution workers' phones except two (86\% and $89 \%$ for institution $\mathrm{A}$ and $\mathrm{C}$ respectively) showed $100 \%$ recovery rate (Table 1).

Antimicrobial susceptibility testing on the recovered isolates showed high levels of resistance in all the isolates ranging from $47 \%$ resistance to Chloramphenicol to $100 \%$ resistance exhibited to cloxacillin. Fifty-five isolates $(55 \%)$ showed resistance to oxacillin (Table 2). ORSA highest occurrence was observed in isolates recovered from laboratory scientists $(60 \%)$, while the least occurrence was recorded amongst isolates from nurses (48.3\%).

Multiple resistance was observed in all the isolates, $20 \%$ showing resistance to all the drugs used while only $8 \%$ resisted just 3 classes of antibiotics. The multiple resistance pattern is shown in Table 3 .

Table 1: Occurrence of Staphylococcus aureus Isolates on Mobile Phones of Health-Care Workers in Ekiti State.

\begin{tabular}{lllllll}
\hline $\begin{array}{l}\text { Hospi- } \\
\text { tal }\end{array}$ & $\begin{array}{l}\text { Doc- } \\
\text { tors }\end{array}$ & $\begin{array}{l}\text { Nurs- } \\
\text { es }\end{array}$ & $\begin{array}{l}\text { Lab } \\
\text { scien- } \\
\text { tist }\end{array}$ & $\begin{array}{l}\text { To- } \\
\text { tal }\end{array}$ & $\begin{array}{l}\text { Growt } \\
\text { h }\end{array}$ & $\begin{array}{l}\text { Percent- } \\
\text { age occur- } \\
\text { rence (\%) }\end{array}$ \\
\hline $3^{\circ} \mathrm{A}$ & 3 & 7 & 4 & 14 & 12 & 85.7 \\
$3^{\circ} \mathrm{B}$ & 3 & 9 & 3 & 15 & 14 & 93.3 \\
$2^{\circ} \mathrm{A}$ & 2 & 5 & 3 & 10 & 10 & 100 \\
$2^{\circ} \mathrm{B}$ & 2 & 5 & 3 & 10 & 10 & 100 \\
$2^{\circ} \mathrm{C}$ & 2 & 6 & 3 & 11 & 11 & 100 \\
$1^{\circ} \mathrm{A}$ & 2 & 7 & 5 & 14 & 12 & 85.7 \\
$1^{\circ} \mathrm{B}$ & 1 & 5 & 2 & 8 & 8 & 100 \\
$1^{\circ} \mathrm{C}$ & 1 & 6 & 2 & 9 & 8 & 88.9 \\
$1^{\circ} \mathrm{D}$ & 1 & 4 & 3 & 8 & 8 & 100 \\
$1^{\circ} \mathrm{E}$ & 1 & 4 & 2 & 7 & 7 & 100 \\
Total & 18 & 58 & 30 & 106 & 100 & 94.3 \\
\hline
\end{tabular}

(Legend: $3^{\circ}=$ tertiary health care institution; $2^{\circ}=$ secondary health care institution; $1^{\circ}=$ primary health care institution)

Table 2: Antibiotic Susceptibility Pattern of Staphylococcus aureus Isolates

\begin{tabular}{llll}
\hline lates & & & \\
Antibiotics & Sensitivity & & \\
& Resistance & Intermediate & Sensitive \\
\hline Oxacillin $(5 \mu \mathrm{g})$ & 55 & 3 & 42 \\
Augmentin $(30 \mu \mathrm{g})$ & 73 & 9 & 18 \\
Amoxycillin & 76 & 7 & 17 \\
Chloramphenicol $(30 \mu \mathrm{g})$ & 47 & 12 & 41 \\
Cotrimoxazole $(25 \mu \mathrm{g})$ & 94 & 3 & 3 \\
Gentamicin & 17 & 10 & 73 \\
Erythromycin $(5 \mu \mathrm{g})$ & 94 & 2 & 4 \\
Tetracycline $(10 \mu \mathrm{g})$ & 73 & 6 & 21 \\
Cloxacillin $(5 \mu \mathrm{g})$ & 100 & 0 & 0 \\
\hline
\end{tabular}


resistance to commonly used antibiotics with the resistance ranging from $17 \%$ to gentamicin to $100 \%$ resistance observed to cloxacillin. These antibiotics are extensively used in Nigeria and often prescribed over the counter [37]. Resistant strains especially Oxacillin resistant $S$. aureus (ORSA) has become the most common cause of nosocomial infections worldwide [38] with this study finding 55\% ORSA isolates. This finding agrees with that reported by [39] who observed $52.5 \%$ ORSA amongst health-care workers of University of Ilorin Teaching Hospital. Also, [40] recovered $20 \%$ S. aureus from 250 phones sampled and observed that they showed high resistance to oxacillin. However, the reports of [41], [42] showed lower recoveries of ORSA with only $4.0 \%$ and $1.8 \%$ in New-Zealand and India respectively. Also, some local studies have reported $\leq 45.0 \%$ ORSA prevalence on patient's isolates [43], [44], and [45]. The differences in the design of these studies may be responsible for the disparity in carriage rates of ORSA as well as the likelihood of poor infection control policies in healthcare settings [46].

Multiple resistance was observed in all ORSA isolates similar to the report of the study by [47] who observed $91.6 \%$ multiple drug resistant isolates from cell phones of clinical workers. Although the development of resistance to antibiotics is a factor of exposure to the antimicrobials [48], other factors may also be responsible [46]. Such multi drug- resistance has serious implications in the treatment of infections caused by these pathogens and for the possible co-selection of antimicrobial resistance mediated by multidrug resistance plasmids [49].

\section{Conclusion}

Although cell phones are important devices for in health care settings, the high prevalence of multiple resistant organisms especially ORSA calls for a review of its use by health workers. Hence, the training of health-care personnel about strict infection control procedure, hand hygiene, environmental disinfection, and eventually, optimum disinfection methods are of great importance. To prevent the emergence of drug resistant forms, indiscriminate use of higher antibiotics needs to be stopped and antibiotic policy to be strictly followed.

\section{References}

[1] Haydon, D.T., Cleaveland, S., Taylor, L.H. Laurenson, M.K. (2002). Identifying reservoirs of infection: A conceptual and practical challenge. Emer. Infect. Dis. 8(12):1468-1473.

[2] Famurewa, O. and David, O.M. (2009). Cell Phone: A Medium of Transmission of Bacterial Pathogens. World Rural Observations 1(2): 69-72.

[3] Hardy, K.J., Oppenheim, B.A., Gossain, S., Gao, F. and Hawkey P.M. (2006). A study of the relationship between environmental contamination with methicillin-resistant Staphylococcus aureus (MRSA) and patients' acquisition of MRSA. Infect. Control Hosp. Epidemiol. 27:127-132. http://dx.doi.org/10.1086/500622.

[4] Marshal, B.M., Ochieng, D.J., Levy, S.B, (2009). Commensals, unappreciated reservoir of antibiotic resistance. Microbe. 4:231 -238.

[5] Brady, R.R. Hunt, A.C. Visvanathan, A., Rodrigues, M.A., Graham, C., Rae, C., Kalima, P., Paterson, H.M. and Gibb, A.P. (2011). Mobile phone technology and hospitalized patients, a crosssectional surveillance study of bacterial colonization, and patient opinions and behaviors. Clin. Microbiol. Infect. 17: 830-835. http://dx.doi.org/10.1111/j.1469-0691.2011.03493.x.

[6] Sadat-Ali, M., Al-Omran, A.K, Azam, Q., Bukari, H., Al-Zahrani, A.J., Al-Turki, R.A., Al-Omran, A.S. (2010). Bacterial flora on cell phones of health care providers in a teaching institution. Am. J. Infect. Control 38:404-405. http://dx.doi.org/10.1016/j.ajic.2009.08.007.

[7] Jeske, H.C., Tiefenthaler, W., Hohlrieder, M., Hinterberger, G., Benzer, A. (2007). Bacterial contamination of anaesthetist's hands by personal mobile phone and fixed phone use in the operating theatre. Anaesthesia. 62:904-906. http://dx.doi.org/10.1111/j.13652044.2007.05172.x.

[8] Meltzer, B. (2003). Nosocomial Infections, Doc's cell phones may spread hospital infection, Outpatient Surg. Mag. 11: 1-4.
[9] Bhattacharya, K (2005). Mobile phone and the Surgeon is there a controversy? Ind. J. Surg, 67: 53-54.

[10] Borer, A., Gilad, J., Smolyakov, R. (2005). Cell phones and Acinetobacter transmission (Online). Emerging Infectious Diseases. 11(7). Available from URL http; www.cdc.gov/eid. http://dx.doi.org/10.3201/eid1107.050221.

[11] Brady R.R., Wasson, A., Stirling I., McAllister C., Damani N.N. (2006). Is your phone bugged? The incidence of bacteria known to cause nosocomial infection on health care workers mobile phones. J. Hosp. Infect. 62: 123-125, 2006 http://dx.doi.org/10.1016/j.jhin.2005.05.005.

[12] Dubik, M. (2006). Use of cell phones in the hospital, AAP Grand Rounds, 15:62-63. http://dx.doi.org/10.1542/gr.15-5-62.

[13] Khivsara, A., Sushma, T. V. Dhanashree, B. (2006). Typing of Staphylococcus aureus from mobile phones and clinical samples, Curr. Sci. 90 (7), 910-912.

[14] Derbyshire, S.W.G. and A. Burgess (2006). Use of mobile phones in hospitals, BMJ. 333(7572): 767-768. http://dx.doi.org/10.1136/bmj.38995.599769.80.

[15] Tambhekar D.H., Gulhane P.G., Dahikar, S.G., Dudhane, M.N. (2008). Nosocomial Hazards of Doctor's Mobile Phones in Hospitals, J. $\quad$ Med. $\quad$ Sci. $\quad 8(1)$ : 73-76. http://dx.doi.org/10.3923/jms.2008.73.76.

[16] Tambe, N.N. and Pai, C. (2012). A Study of Microbial Flora and MRSA Harboured by Mobile Phones of Health Care Personnel. International Journal of Recent Trends in Science and Technology, 4(1): 14-18.

[17] Breves, A., Miranda, C.A.C., Flores, C., de Filippis, I. and Clementino, M.M. (2015). Methicillin- and vancomycin-resistant Staphylococcus aureus in health care workers and medical devices. J. Bras. Patol. Med. Lab. 51(3), 143-152. http://dx.doi.org/10.5935/16762444.20150025.

[18] Cavalcanti, S.M.M., França, E.R., Vilela, M.A., Montenegro, F., Cabral, C., Medeiros, A.C.R. (2006). Estudo comparativo da prevalência de Staphylococcus aureus importado para as unidades de terapia intensiva de Hospital Universitário, Pernambuco, Brasil. Rev. Bras. Epidemiol. 9: 436-446. http://dx.doi.org/10.1590/S1415790X2006000400004.

[19] Jevons, M.P. (1961). "Celebenin" - resistant Staphylococci. British Medical Journal, 124. http://dx.doi.org/10.1136/bmj.1.5219.124-a.

[20] Kock, R., Becker, K., Cookson, B., van Gemert-Pijnen, J.E., Harbarth, S., Kluytmans, J., Mielke, M., Peters, G., Skov, R.L., Struelens, M.J., Tacconelli, E., Navarro Torne, A., Witte, W., Friedrich, A.W. (2010). Methicillin-resistant Staphylococcus aureus (MRSA), burden of disease and control challenges in Europe. Euro surveillance, bulletin europeen sur les maladies transmissibles = European communicable disease bulletin 15(41), 19688.

[21] Grundmann, H., Aires-de-Sousa, M., Boyce, J., Tiemersma, E. (2006). Emergence and resurgence of meticillin-resistant Staphylococcus aureus as a public-health threat. Lancet 368(9538): 874-85 http://dx.doi.org/10.1016/S0140-6736(06)68853-3.

[22] Hsueh, P.R., Teng, L.J., Chen, W.H., Pan, H.J., Chen, M.L., Chang, S.C., Luh, K.T., Lin, F.Y. (2004). Increasing prevalence of methicillin-resistant Staphylococcus aureus causing nosocomial infections at a university hospital in Taiwan from 1986 to 2001. Antimicrobial agents and Chemotherapy 48(4): 1361-4. http://dx.doi.org/10.1128/AAC.48.4.1361-1364.2004.

[23] Mulligan, M.E., Standiford, H.C., Kauffman, C.A. (1992). 'Methicillin resistant Staphylococcus aureus, a consensus review of the microbiology, pathogenesis, and epidemiology with implications for prevention and management' Am. J. Med. 94:313-328. http://dx.doi.org/10.1016/0002-9343(93)90063-U.

[24] Lee, J.H., (2003). Methicillin (Oxacillin)-Resistant S. aureus Strains Isolated from Major Food Animals and Their Potentia Transmission to Humans. Applied and Environmental Microbiology 69(11), 6489-6494. http://dx.doi.org/10.1128/AEM.69.11.6489$\underline{6494.2003}$

[25] Murray, P. R., Baron, E. J., Jorgensen, J. H., Pfaller, M. A., Yolken, R. H. (2003). Manual of Clinical Microbiology, 8th edn. American Society for Microbiology; Washington, DC, USA.

[26] Verhoef J, Blok H, Baars A, et al. (1999). A Dutch Approach to Methicillin-Resistant Staphylococcus aureus. Eur. J. Clin. Microbiol. Infect. Dis. 18:461. http://dx.doi.org/10.1007/s100960050324.

[27] Diekema, D.J., Pfaller, M.A., et al. (2000). Genetic relatedness of multidrug- resistant, methicillin (oxacillin)-resistant Staphylococcus aureus bloodstream isolates form SENTRY Antimicrobial Resistance Surveillance Centers worldwide, 1998. Microb. Drug Resist. 6: 213-21. http://dx.doi.org/10.1089/mdr.2000.6.213.

[28] Gorwitz, J., Jernigan, D.B., Powers, J. H. et al. (2006). Strategies for Clinical Management of MRSA in the Community, Summary of 
Experts' Meeting Convened by the Centre for Disease Control and Prevention. USA.

[29] Fawole, M. O. and Oso, B. A. (2001). Laboratory Manual of Microbiology. Spectrum Books Limited, Ibadan, 127pp.

[30] Holt, J.G., Krieg, N.R., Sneath, P.H.A., Staley, J.T., Williams, S.T (1994). Bergey's Manual of Determinative Bacteriology. 9th edition. Baltimore: Williams and Wilkins; 1: 141-199.

[31] Clinical and Laboratory Standards Institute (CLSI) 2012) Performance Standards for Antimicrobial Susceptibility Testing, Wayne, PA. USA, 4(1).

[32] Pal, S., Juyal, D., Adekhandi, S, Sharma, M., Prakash, R., Sharma, N., Rana, A., Parihar, A. (2015). Mobile phones, Reservoirs for the transmission of nosocomial pathogens. Adv Biomed Res. 4,144 http://dx.doi.org/10.4103/2277-9175.161553.

[33] Akinyemi, K.O., Atapu, A.D., Adetona, O.O., Coker, A.O. (2009). The potential role of mobile phones in the spread of bacterial infections. J. Infect. Dev. Ctries. 3(8): 628-632. http://dx.doi.org/10.3855/jidc.556.

[34] Selim, H.S. and Abaza, A.F. (2015). Microbial contamination of mobile phones in a health care setting in Alexandria, Egypt. GMS Hyg. Infect. Control. 10.

[35] Bhat, S.S., Sundeep H.K., Shailaja S. (2011). Potential of Mobile Phones to Serve as a Reservoir in Spread of Nosocomial Pathogens. Online Journal of Health and Allied Sciences. 10(2): 1-3.

[36] Angadi, K.M. Misra, R., Gupta, U., Jadhav, S., Sardar, M. (2014). Study of the role of mobile phones in the transmission of Hospital acquired infections. Accessible at www.mjdrdypu.org 7(4): 435438. DOI, $10.4103 / 0975-2870.135256$.

[37] Olowe, O.A., Okanlawon, B.M., Olowe, R.A., Olayemi, A.B (2008). Antimicrobial resistant pattern of Escherichia coli from human clinical samples in Osogbo, south western Nigeria. Afr. J. Microbiol. Res., 2: 008-011.

[38] Taiwo, S. S., Bamidele, M., Omonigbehin, E. A., Akinsinde, K. A., Smith, S. I., Onile, B. A., Olowe, A. O. (2005), Molecular epidemiology of methicillin-resistant $S$. aureus in Ilorin, Nigeria. West Afr. J. Med. 24:100-106. http://dx.doi.org/10.4314/wajm.v24i2.28176.

[39] Fadeyi, A., Bolagi, B.O., Oyedepo, O.O., Adesiyun, O.O. Adeboye, M.A.N., Olarewaju, T.O., Aderigbe, A., Salami, A.K., Desalu, O.O., Fowotade, A., Nwabuisi, C., Akanbi II, A.A., Raheem, R.A., Olare, A. (2010), "Methicillin-resistance Staphylococcus aureus carriage amongst health-care workers of the critical care units in a Nigerian hospital". Am. J Infect Dis. 6(1): 18-23. http://dx.doi.org/10.3844/ajidsp.2010.18.23.

[40] Sedighi, I., Alikhani M.Y., Ramezani S., Nazari, M. and Nejad, A.S.M. (2015). Bacterial Contamination of Mobile Phones of Health Care Providers in a Teaching Hospital in Hamadan Province, Iran. Arch Clin Infect Dis. 10(2), e22104. http://dx.doi.org/10.5812/archcid.10(2)2015.22104.

[41] Fadheel, Z.H., H.E. Perry and R.A. Henderson, (2008). Comparison of Methicillin-Resistant Staphylococcus aureus (MRSA) carriage rate in the general population with the health-worker population (Clinical report). N. Zealand J. Med. Lab. Sci., 62, 4-6. http,//www.nzimls.org.nz/121.html?articles id=112

[42] Mathanraj, S., Sujatha, S. Sivasangeetha, K. and Parija, S.C. (2009). Screening for methicillin-resistant $S$. aureus carriers among patients and health care workers of a tertiary care hospital in Southern India. Indian J. Med. Microbiol., 27, 62-64.

[43] Taiwo, S.S., Onile, B.A., Akanbi, A.A. (2004). "Methicillin resistant S. aureus (MRSA) isolates in Ilorin, Nigeria," African Journal of Clinical and Experimental Microbiology, 5(2):189-197. http://dx.doi.org/10.4314/ajcem.v5i2.7376.

[44] Adesida, S., Boelens, H. Babajide, B. Kehinde, A., Snijders S. (2005). Major epidemic clones of Staphylococcus aureus in Nigeria. Microb. Drug Resist. 11: 115-121. http://dx.doi.org/10.1089/mdr.2005.11.115.

[45] Azeez-Akande, O., Utsalo, S.J. and Epoke, J. (2008). Distribution and antibiotic susceptibility pattern of methicillin-resistant Staphylococcus aureus isolates in a university Teaching hospital in Nigeria. Sahel Med. J. 11, 142-147.

[46] Daka, D. (2014). Antibiotic- resistant Staphylococcus aureus isolated from mobile phones and hands of health-care workers in the Hawassa referral hospital, South Ethiopia. Journal of Microbiology and Antimicrobials. 6(4), 72-78 http://dx.doi.org/10.5897/JMA2014.0303.

[47] Jayalakshmi, J., Appalaraju, B. and Usha S. (2008). Cell phones asreservoir of nosocomial pathogens. JAPI. 56, 388- 389.

[48] Rychlik, I. Gregorova, D. and Hradecka, H. (2006). Distribution and function of plasmids in Salmonella enterica. Veterinary Microbiology 112, 1-10. http://dx.doi.org/10.1016/j.vetmic.2005.10.030.
[49] Sherley, M., Gardon, D.M. and Collingnon, P.J. (2004). Evolution of multi-resistance plasmids in Australia clinical isolates of Escherichia coli. Microbiology. 150, 1539-1546. http://dx.doi.org/10.1099/mic.0.26773-0. 